\title{
Effect of the Nutrient Composition of Biodegraded Sweet Orange (Citrus sinensis) Fruit Peel on the Growth Performance of Starter Broiler Chicks
}

\author{
Timothy Adewale Odunlade ${ }^{1}$, Oluwabiyi Ikeolu Atanda Oluremi ${ }^{2,}$, Favour Bette Patrick Abang ${ }^{1}$ \\ ${ }^{1}$ Department of Animal Production, Federal University of Agriculture, Makurdi, Nigeria \\ ${ }^{2}$ Department of Animal Science, The National University of Lesotho, Roma, Lesotho
}

Email address:

oiaoluremi@yahoo.com (O. I. A. Oluremi)

${ }^{*}$ Corresponding author

\section{To cite this article:}

Timothy Adewale Odunlade, Oluwabiyi Ikeolu Atanda Oluremi, Favour Bette Patrick Abang. Effect of the Nutrient Composition of Biodegraded Sweet Orange (Citrus sinensis) Fruit Peel on the Growth Performance of Starter Broiler Chicks. Animal and Veterinary Sciences. Vol. 8, No. 5, 2020, pp. 104-109. doi: 10.11648/j.avs.20200805.13

Received: August 11, 2020; Accepted: August 22, 2020; Published: September 24, 2020

\begin{abstract}
A twenty-eight (28) day feeding trial was conducted to determine the nutrient composition of biodegraded sweet orange (Citrus sinensis) fruit peel and its potential as an energy source in the nutrition of starter broiler chicks. Rumen content was collected from freshly slaughtered cattle and, fresh sweet orange fruit peels (SOP) were collected from orange fruit retailers. The rumen content was mixed with water at ratio $1 \mathrm{~kg}$ : 1 Land sieved to obtain rumen filtrate (RF). The fresh sweet orange peels were divided into four equal parts in weight; T1, T2, T3 and T4, and soaked in the rumen filtrate at ratio $1 \mathrm{~kg}$ : $1 \mathrm{~L}$ in air-tight bags for $12 \mathrm{~h}, 24 \mathrm{~h}, 36 \mathrm{~h}$ and $48 \mathrm{~h}$, respectively. The biodegraded sweet orange peels (BSOP) were sun-dried to a moisture level of about $10 \%$, milled and each used to replace $30 \%$ of maize in the control diet (CD) to obtain broiler starter test diets $T_{1} D, T_{2} D, T_{3} D$ and $T_{4} D$, respectively. Chemical analyses were carried out to determine their proximate composition and fibre fractions while, metabolizable energy content was calculated. The results showed that BSOP contained CP, CF, EE, Ash, NFE and metabolizable energy in the range of $6.78 \%-7.30 \%, 10.36 \%-12.30 \%, 1.88 \%-2.65 \%, 7.79 \%-11.76 \%, 66.04 \%-72.46 \%$ and $2829.44 \mathrm{kcal} / \mathrm{kg}-3037.97 \mathrm{kcal} / \mathrm{kg}$, respectively. The BSOP had ADF, NDF, ADL, hemicellulose and cellulose in the range of $19.50 \%-22.50 \%, 52.30 \%-56.70 \%, 6.80 \%-8.40 \%, 32.80 \%-34.20 \%$ and $12.90 \%-14.40 \%$, respectively. A total of one hundred and eighty day old broiler chicks (Ross 308) were randomly assigned to five dietary treatments replicated three times with equal number and similar weights in a completely randomized design. The experimental diets had significant ( $<<0.05)$ on the final weight, weight gain feed intake, feed conversion ratio, protein intake, protein efficiency ratio and mortality. The birds fed the BSOP based diets had similar non-significant $(p>0.05)$ and inferior values to the birds on the maize based control diet suggesting that time duration of $12 \mathrm{~h}, 24 \mathrm{~h}, 36 \mathrm{~h}$ and $48 \mathrm{~h}$ given for biodegradation of sweet orange peel could not enhance its nutrients. Biodegradation of sweet orange fruit peel for a time frame of $12 \mathrm{~h}$ to $48 \mathrm{~h}$ yielded a feed ingredient with a relatively high crude fibre, which lowered the growth rate of starter broiler chicks and cannot be used to formulate starter chicks diet at $30 \%$ maize replacement.
\end{abstract}

Keywords: Rumen Content, Biodegradation Duration, Feed Value

\section{Introduction}

Animal protein is essential in human nutrition because of its biological significance, due to the similarity of its amino acid profile to that of man. The poultry industry is one of the fastest means of providing the much-needed animal protein to reduce shortage in its consumption by man. This requires optimal management and nutrition to reduce costs and economize poultry meat production to offer high quality products to consumers $[1,2]$. In developing countries, the increasing cost and decreasing supply of conventional feedstuffs are expected to constrain the future expansion of the livestock industry [3]. The cost of feed alone accounts for about $70-75 \%$ of the total cost of broiler production and this 
may pose a threat to poultry production in terms of profitability [4]. Exploring the vast non-conventional plants and agricultural by-products which are abundantly available for possible utilisation in non-ruminant animal feeding is a feasible option. This may precipitate less dependence on the expensive and competed for conventional feed stuffs, with concomitant reduction in the cost of animal production developing countries. Large quantities of agricultural byproducts, which are regarded as non-conventional feed sources are produced in Nigeria. Some agro-industrial byproducts such as cocoa husk meal [5], cassava root meal/brewery yeast slurry [6], citrus peel meals [7], biodegraded sweet orange peel [8], palm oil sludge [9], composite mango fruit reject meal $[10,11]$ have been used to replace cereal grains in poultry and rabbit diets.

Nigeria is one of the largest producers of citrus in Africa with about 14 states being major producers [12]. Orange production in Nigeria has been recently reported to be about 4.07 million tonnes has been recently reported [13]. A large percentage of these citrus fruits are either supplied to agroprocessing industries for processing into various consumable products and/or consumed fresh after removing the peel locally. Whichever way the citrus fruits are handled, many by-products are generated which consist of peel, pulp and seeds. Processing of citrus fruits can generate on dry matter basis $60-65 \%$ peel, $30-35 \%$ pulp and $0-10 \%$ seed, depending on the variety [14]. Sweet orange (Citrus sinensis) fruit peel is abundant in Nigeria all year round, and has been reported to be high in crude fibre and energy [15]. Sweet orange fruit peel is a source of calorie and protein comparable to maize [7], and maize can be replaced by sun dried sweet orange rind in broiler starter diet at $20 \%$ for optimal performance and nutrient utilization [16]. In spite of the high energy content of sweet orange peel, the high crude fibre level places a limitation on its feed value in broiler chicken nutrition and production, hence the need to subject it to some form of processing to enhance its dietary energy replacement value. Rumen content is an important animal by-product in the abattoir industry in Nigeria because of the high population of beef cattle providing meat for over 206 million Nigerians [17]. It can be converted into a beneficial use by taking advantage of its microbial population for the processing of sweet orange fruit peel for value addition so as to enhance the suitability of sweet orange peel as dietary energy source for livestock production. This research was therefore aimed at evaluating the effect of biodegraded sweet orange fruit peel on the performance of starter broiler chicks.

\section{Materials and Methods}

\subsection{Experimental Site}

The study was carried out at the Poultry unit of the Livestock Teaching and Research Farm of the College of Animal Science, Federal University of Agriculture Makurdi, Benue State, Nigeria. Makurdi is located on latitude $7^{\circ} 43^{\prime}$ $50^{\prime \prime} \mathrm{N}$ and longitude $8^{\circ} \mathrm{C} 32^{\prime} 10^{\prime \prime} \mathrm{N}$ [18] and, lies within the guinea savannah region of Nigeria. It has two distinct seasons; the wet (April to October) and dry (November to March) seasons. The lowest temperature range is $19-26^{\circ} \mathrm{C}$ and the highest temperature range is $28-36^{\circ} \mathrm{C}$ with an annual average rainfall of $1224.50 \mathrm{~mm}$ [19]. The annual relative humidity ranges between $47 \%$ and $85 \%$ [20].

\subsection{The Source, Biodegradation of Sweet Orange Peel and Preparation of Experimental Diets}

Fresh sweet orange (Citrus sinensis) fruit peels were collected from orange fruit sellers in the University town of Makurdi. Rumen content was obtained at the Modern Market Abattoir in Makurdi, and put in sealed plastic buckets. Rumen content was thoroughly mixed with water at ratio $1 \mathrm{~kg}$ : $1 \mathrm{~L}$, and then sieved into a bucket to get rumen filtrate. The fresh sweet orange peels (SOP) were divided into four equal parts in weight; T1, T2, T3 and T4, and soaked in the rumen filtrate at ratio $1 \mathrm{~kg}$ : $1 \mathrm{~L}$ in air-tight bags for $12 \mathrm{~h}, 24 \mathrm{~h}$, $36 \mathrm{~h}$ and $48 \mathrm{~h}$, respectively. The biodegraded sweet orange peels (BSOP) were sun-dried to a moisture level of about $10 \%$, and bagged. Each treatment was milled and representative samples analysed to determine the proximate constituents [21] and the fibre fractions [22] while, metabolisable energy was calculated [23]. Each of the remaining milled peels was mixed with other feed ingredients to compound four test experimental diets $\mathrm{T}_{1} \mathrm{D}, \mathrm{T}_{2} \mathrm{D}, \mathrm{T}_{3} \mathrm{D}$, and $\mathrm{T}_{4} \mathrm{D}$ in which dietary maize in control diet (CD) was replaced with $30 \%$ of $\mathrm{T}_{1}, \mathrm{~T}_{2}, \mathrm{~T}_{3}$ and $\mathrm{T}_{4}$, respectively (Table 1 ).

Table 1. Composition of Broiler Starter Experimental Diets.

\begin{tabular}{lllll}
\hline Experimental Diets & & & & \\
\hline Ingredients (kg) & CD & $\mathbf{T}_{\mathbf{1}} \mathbf{D}$ & $\mathbf{T}_{\mathbf{2}} \mathbf{D}$ & $\mathbf{T}_{\mathbf{3}} \mathbf{D}$ \\
\hline Maize & 55.60 & 38.92 & 38.92 & 38.92 \\
BSOP & 4.00 & 16.68 & 16.68 & 16.68 \\
Brewers dried grain & - & 4.00 & 4.00 & 38.92 \\
Soyabean meal & 34.60 & 34.60 & 34.60 & 16.68 \\
Blood meal & 1.80 & 1.80 & 1.80 & 34.60 \\
Limestone & 1.00 & 1.00 & 1.00 & 1.80 \\
Bone ash & 2.00 & 2.00 & 2.00 & 1.00 \\
DL-Methionine & 0.25 & 0.25 & 0.25 & 2.00 \\
L-Lysine & 0.25 & 0.25 & 0.25 & 0.25 \\
Premix & 0.25 & 0.25 & 0.25 & 0.25 \\
Common salt & 0.25 & 0.25 & 0.25 & 0.25 \\
Total & 100.00 & 100.00 & 0.00 \\
\hline
\end{tabular}




\begin{tabular}{llllll}
\hline Experimental Diets & & & & & \\
\hline Ingredients (kg) & CD & $\mathbf{T}_{\mathbf{1}} \mathbf{D}$ & $\mathbf{T}_{\mathbf{2}} \mathbf{D}$ & $\mathbf{T}_{\mathbf{3}} \mathbf{D}$ & $\mathbf{T}_{\mathbf{4}} \mathbf{D}$ \\
\hline Calculated analysis: & & & & & \\
ME (Kcal/kg) & 2886.32 & 2820.60 & 2798.75 & 2808.78 & 2785.81 \\
Crude protein (\%) & 22.68 & 22.33 & 22.41 & 22.41 & 22.41 \\
Ether extract (\%) & 3.88 & 3.65 & 3.54 & 3.53 & 3.65 \\
Crude fibre (\%) & 4.24 & 5.49 & 5.76 & 5.69 & 5.85 \\
Calcium (\%) & 1.29 & 1.29 & 1.29 & 1.29 & 1.29 \\
Available P (\%) & 0.71 & 0.66 & 0.66 & 0.66 & 0.66 \\
Lysine (\%) & 1.48 & 1.44 & 1.44 & 1.44 & 1.44 \\
Methionine (\%) & 0.74 & 0.70 & 0.70 & 0.70 & 0.70 \\
\hline
\end{tabular}

"Premix supplies per kg: Vitamin A, 10,000, 000 iu., Vitamin $\mathrm{D}_{3}$, 2,000,000 mg., Vitamin $\mathrm{K}_{3}$ 2,000 mg., Vitamin $\mathrm{B}_{1,}$ 3,000 mg., VitaminB $\mathrm{B}_{2}$ 5,000 mg., Niacin, 45,000 mg., Calcium panthothenate, $10,000 \mathrm{mg}$., Vitamin $\mathrm{B}_{6}, 4,000 \mathrm{mg}$., Vitamin $\mathrm{B}_{12}, 20 \mathrm{mg}$., Choline chloride, 300,000 mg., Folic acid, 1,000 mg., Biotin, 50 mg., Manganese 300,000 mg., Iron 120,000 mg,. Zinc, 80,000 mg., Copper, 8,500 mg., Iodine, 1,500 mg., Cabot, 300 mg., Selenium 120 mg., Antioxidant $120,000 \mathrm{mg}$., BSOP $=$ Biodegraded sweet orange peel.

$\mathrm{CD}=$ Control diet containing $0 \%$ biodegraded sweet orange peel, $\mathrm{T}_{1} \mathrm{D}=$ Diet containing sweet orange peel obtained after $12 \mathrm{~h}$ biodegradation, $\mathrm{T}_{2} \mathrm{D}=$ containing sweet orange peel obtained after $24 \mathrm{~h}$ biodegradation, $\mathrm{T}_{3} \mathrm{D}=$ containing sweet orange peel obtained after $36 \mathrm{~h}$ biodegradation, $\mathrm{T}_{4} \mathrm{D}=$ containing sweet orange peel obtained after $48 \mathrm{~h}$ biodegradation.

$\mathrm{ME}=37(\% \mathrm{CP})+81.8(\% \mathrm{EE})+35.5(\% \mathrm{NFE})-($ Pauzenga, 1985$)$.

\subsection{Experimental Birds and Management}

A total of one hundred and eighty (180) day old broiler chicks (Ross 308) from Sayed Farms were used in the feeding trial. The birds were randomly grouped into five (5) of equal number (36) and similar weight. A group each was assigned also randomly to one of the five (5) experimental diets with three (3) replicates of twelve (12) birds each. The birds were housed in a half-walled deep litter pen with wood shaving as the litter material. The birds were fed ad-libitum throughout a 28-day feeding trial and allowed free access to drinking water. Health management protocols involved the administration of infectious bursal disease vaccine (Gumboro) at $10^{\text {th }}$ and $21^{\text {st }}$ days, Newcastle disease vaccine (Lasota) at $14^{\text {th }}$ and $28^{\text {th }}$ days. Anti-stress supplement (vitalyte) was administered at day old, prior to and after each vaccine administration, pre and post weekly weighing of birds. Antibiotics and coccidiostat were also administered routinely each at alternate weeks as prophylactic measures against bacterial infection and coccidiosis.

\subsection{Growth Performance Data}

Initial and final live weights of the birds were taken at the start and end of the feeding trial using a top-load weighing scale. Weekly body weights were also recorded. Body weight gain (BWG) was determined by weight difference between current and previous weeks, while total weight gain was obtained by the difference between the final and initial live weights. Feed intake was obtained from the amount of feed supplied less the left over. Feed conversion ratio (FCR) was calculated from the ratio of feed consumed to body weight gain $(\mathrm{FCR}=$ Feed consumed $/ \mathrm{BWG})$ while, protein efficiency ratio (PER) was computed from the ratio of body weight gain to protein consumed $(\mathrm{PER}=\mathrm{BWG} /$ protein consumed).

\subsection{Statistical Analysis}

Data generated were subjected to one-way analysis of variance (ANOVA) using [24] and the means of significantly different $(\mathrm{p}<0.05)$ parameters were separated using the Duncan's Multiple Range Test (DMRT) of the same software package.

\section{Results and Discussion}

The proximate composition and metabolizable energy of sweet orange (Citrus sinensis) fruit peel obtained after $12 \mathrm{~h}$, $24 \mathrm{~h}, 36 \mathrm{~h}$ and $48 \mathrm{~h}$ biodegradation are presented in Table 2. The crude protein values of the biodegraded sweet orange peel were lower than $8.90 \% \mathrm{CP}$ in maize, a conventional energy feedstuff [25] used in the formulation of broiler chicken diet. This showed that the biodegraded sweet orange peel used in this study was inferior to maize in crude protein. Higher crude proteins of $10.73 \%$ [26] and $8.20 \%$ [27] have been reported for non-biodegraded sun dried sweet orange peels. The variation of the $\mathrm{CP}$ in this study from those reported by these workers can largely be attributed to the different processing and handling methods. The differences in per cent crude protein present in sweet orange peel reported by the different researchers could be attributed to differences in varieties of orange fruits, season of the year the peels were gathered, processing techniques adopted and the stage of maturity at which the fruits were harvested. The crude fibre $(\mathrm{CF})$ range observed in this study $(10.16 \%$ to $12.30 \%$ ) was higher than $2.70 \%$ for maize [25] and $7.86 \%$ reported for sun dried sweet orange peel [26]. Thus, the biodegradation method used was unable to cause an appreciable reduction in the fibre content of the peel so as to increase its potential use as energy feed ingredient in broiler chicken diet. High fibre level in a feed limits its use in broiler chicken diet. The ether extract (EE) range reported in this study was lower than $4.00 \%$ for maize [25]. This may have been responsible for the reduction in carcass visceral fat in a study to evaluate the effect of fermented sweet orange peel on broiler chicken performance, in which lower fat levels in the range of 2.33-2.94\% was found in the peel [28] compared to $4.00 \%$ in maize; the standard reference energy ingredient. The ash content in the biodegraded orange peel was higher than $2.36 \%$ for maize [29] and $6.09 \%$ [27] for orange peel 
sun dried immediately after collection. Hence, the rumen filtrate may have raised the ash content during biodegradation. Nitrogen free extract (NFE) in this study tended to decrease as the duration of biodegradation of sweet orange peel increased from 0 to $48 \mathrm{~h}$. The possible increase in the growth and proliferation of microbes during biodegradation may be responsible for the reduction of NFE as they will utilize more of the soluble carbohydrates as source of metabolic energy as the duration of the process increased. The metabolisable energy of the biodegraded sweet orange peel had the same trend as the NFE, and lower than $3432 \mathrm{kcal} / \mathrm{kg}$ of maize [30]. The result of proximate composition of biodegraded sweet orange peel has elicited the possibility of its being useable in broiler chicken diets if the high fibre content can be reduced by the application of any feed processing method, including microbial technology experimented in this trial.

The quantification of the crude fibre fractions in biodegraded sweet orange (Citrus sinensis) fruit peel is presented in Table 3. The duration of 0 to $48 \mathrm{~h}$ given for biodegradation of sweet orange peel did not cause significant $(p>0.05)$ variation in the acid detergent fibre (ADF), neutral detergent fibre (NDF), acid detergent lignin (ADL), hemicellulose and cellulose fractions among the treatments. They all appear to decrease marginally as the duration of biodegradation increased. It is this same pattern that was observed in the feed intake of the birds in this study. The level of NDF, ADF, ADL and cellulose in feed stuff are negatively correlated to feed intake of monogastric animals and most especially poultry and pig. This is because of their intrinsic gastrointestinal tract limitation to digest fibrolytic carbohydrates due to the absence of anaerobic bacteria which are carbohydrate fermenters to release energy for their utilisation. Hence, lower amounts of these fibrolytic materials in broiler feed will help to improve feed intake for adequate energy utilisation for productive purposes. The $\mathrm{ADF}, \mathrm{NDF}$, and cellulose fractions obtained in this study were comparatively lower than $38.84 \%$ to $41.39 \%$ ADF, $60.00 \%$ to $62.5 \%$ NDF, $33.35 \%$ to $35.26 \%$ cellulose, respectively while, the ADL and hemicellulose were higher than $5.44 \%$ to $5.62 \% \quad \mathrm{ADL}$ and $21.21 \%$ to $21.62 \%$ hemicellulose, respectively earlier reported [31]. These variations might be due to the differences in the production of fibrolytic enzymes according to the substrates and microorganisms during fermentation [32].

Table 2. Proximate Composition and Metabolizable Energy of Biodegraded Sweet Orange Fruit Peel Meal (\% DM).

\begin{tabular}{|c|c|c|c|c|}
\hline \multicolumn{5}{|c|}{ Biodegraded Sweet Orange Peel Meal } \\
\hline Parameters & $\mathrm{BSOP}_{12}$ & BSOP $_{24}$ & BSOP $_{36}$ & BSOP $_{48}$ \\
\hline Dry matter & 90.43 & 90.38 & 89.82 & 90.50 \\
\hline Crude protein & 6.78 & 7.26 & 7.30 & 7.25 \\
\hline Crude fibre & 10.16 & 11.76 & 11.38 & 12.30 \\
\hline Ether extract & 2.63 & 1.97 & 1.88 & 2.65 \\
\hline Ash & 7.97 & 9.23 & 7.79 & 11.76 \\
\hline Nitrogen free extract & 72.46 & 69.78 & 71.65 & 66.04 \\
\hline
\end{tabular}

BSOP $_{12}$ : Biodegraded sweet orange peels obtained after $12 \mathrm{~h}$ fermentation. $\mathrm{BSOP}_{24}$ : Biodegraded sweet orange peels obtained after $24 \mathrm{~h}$ fermentation. $\mathrm{BSOP}_{36}$ : Biodegraded sweet orange peels obtained after $36 \mathrm{~h}$ fermentation. BSOP $_{48}$ : Biodegraded sweet orange peels obtained after $48 \mathrm{~h}$ fermentation. Metabolizable energy $=37(\% \mathrm{CP})+81.8(\% \mathrm{EE})+35.5(\% \mathrm{NFE})($ Pauzenga, 1985)

Table 3. Fibre Fractions in Biodegraded Sweet Orange Fruit Peel Meal (\% DM).

\begin{tabular}{lllll}
\hline \multicolumn{2}{l}{ Biodegraded Sweet Orange Peel Meal } & & \\
\hline Fibre fractions & BSOP $_{\mathbf{1 2}}$ & BSOP $_{\mathbf{2 4}}$ & BSOP $_{\mathbf{3 6}}$ \\
\hline ADF & 22.30 & 21.20 & 22.50 & \\
NDF & 56.10 & 54.40 & 56.70 & 19.50 \\
ADL & 8.40 & 7.60 & 8.10 & 52.30 \\
Hemicellulose & 33.80 & 33.20 & 34.20 & 6.80 \\
Cellulose & 13.90 & 13.60 & 14.40 & 32.80 \\
\hline
\end{tabular}

ADF: Acid detergent fibre, NDF: Neutral detergent fibre, ADL: Acid detergent lignin.

$\mathrm{BSOP}_{12}$ : Sweet orange peels obtained after $12 \mathrm{~h}$ biodegradation.

$\mathrm{BSOP}_{24}$ : Sweet orange peels obtained after $24 \mathrm{~h}$ biodegradation.

$\mathrm{BSOP}_{36}$ : Sweet orange peels obtained after $36 \mathrm{~h}$ biodegradation.

BSOP $_{48}$ : Sweet orange peels obtained after $48 \mathrm{~h}$ biodegradation.

The performance of starter broiler chicks in the feeding trial is presented in Table 4. The mean final live body weight of starter broiler chicks showed that the birds in the control group (CD) were significantly $(\mathrm{p}<0.05)$ heavier than the birds in the biodegraded sweet orange peel meal (BSOP) based diets. This is possibly a direct consequence of the nature of the experimental diets because, the biodegraded sweet orange peel used as a replacement for maize at $30 \%$ level had a lower feed value due to its high fibre content. This conferred lower nutrient status on the BSOP based diets hence, the significant $(p<0.05)$ variation in the body weight between the chicks in the control and the test diet groups. The birds fed the BSOP 
based diets had similar final live body weight which showed that the time allowed for biodegradation of sweet orange peel which ranged from $12 \mathrm{~h}$ to $48 \mathrm{~h}$ did not enhance the nutrients in it. The broiler starter live weight obtained agrees with $491.00 \mathrm{~g}$ to $831.67 \mathrm{~g}$ when sweet orange peel meal was incorporated into broiler chick diets [15], and it has been earlier reported that broiler chickens on control diets were heavier than those on sweet orange peel meal-based diets [28, $33,34]$. The total weight gain, daily weight gain, feed conversion ratio and protein efficiency ratio also differed significantly $(p<0.05)$ and followed the same trend as the final weight. Daily feed intake and protein intake were also affected significantly $(\mathrm{p}<0.05)$ by the experimental diets with a direct relationship between these performance indicators. The daily feed intake obtained in this study was observed to be comparable to $37.28 \mathrm{~g}$ to $44.64 \mathrm{~g}$ obtained when exogenous enzyme was added to treat sweet orange peel used as replacement for maize [27] but, lower than $52.68 \mathrm{~g}$ to $62.56 \mathrm{~g}$ reported by [26] when sun-dried sweet orange peel meal was used in broiler starter diets. Birds fed diets containing biodegraded sweet orange peel meal had similar daily feed intake, feed conversion ratio and daily protein intake. This suggests that biodegradation of sweet orange peel using rumen filtrate from cattle for durations of $12 \mathrm{~h}$ to $48 \mathrm{~h}$ did not upgrade the feed quality of sweet orange peel. Feed conversion ratio (FCR) obtained was similar to 1.54-1.70 when exogenous enzyme was used to treat sweet orange peel [27]. Feed conversion rate is usually low for young animals because of their fast relative growth, and increases for older animals when relative growth tends to flatten out and feed intake is high. Mortality occurred in all the dietary groups with a pattern difficult to link to the experimental diets. An earlier report on sweet orange peel meal showed $0 \%$ mortality even at higher percentages of maize replacement with sweet orange peel [35].

Table 4. Performance of Starter Broiler Chicks fed Diets Containing Biodegraded Sweet Orange Peel Meal.

\begin{tabular}{|c|c|c|c|c|c|c|}
\hline \multicolumn{7}{|l|}{ Experimental Diets } \\
\hline Performance Indices & CD & $\mathbf{T}_{1} \mathbf{D}$ & $\mathbf{T}_{2} \mathbf{D}$ & $\mathbf{T}_{3} \mathbf{D}$ & $\mathbf{T}_{4} \mathbf{D}$ & SEM \\
\hline Initial live weight ( $\mathrm{g} / \mathrm{bird}$ ) & 36.11 & 35.42 & 36.11 & 35.42 & 36.11 & $0.54^{\text {ns }}$ \\
\hline Final live weight (g/bird) & $811.43^{\mathrm{a}}$ & $617.20^{\mathrm{b}}$ & $590.97^{\mathrm{b}}$ & $576.14^{\mathrm{b}}$ & $583.83^{\mathrm{b}}$ & 24.73 \\
\hline Total weight gain (g/bird) & $775.31^{\mathrm{a}}$ & $581.78^{\mathrm{b}}$ & $554.86^{\mathrm{b}}$ & $540.72^{\mathrm{b}}$ & $547.72^{\mathrm{b}}$ & 24.37 \\
\hline Daily weight gain ( $\mathrm{g} /$ bird/day) & $27.69^{\mathrm{a}}$ & $20.73^{\mathrm{b}}$ & $19.82^{\mathrm{b}}$ & $19.31^{\mathrm{b}}$ & $19.56^{\mathrm{b}}$ & 0.87 \\
\hline Daily feed intake (g/bird/day) & $43.06^{\mathrm{a}}$ & $40.62^{\mathrm{ab}}$ & $38.67^{\mathrm{ab}}$ & $38.47^{\mathrm{b}}$ & $38.21^{\mathrm{b}}$ & 1.35 \\
\hline Feed conversion ratio & $1.56^{\mathrm{b}}$ & $1.95^{\mathrm{a}}$ & $1.95^{\mathrm{a}}$ & $1.99^{\mathrm{a}}$ & $1.95^{\mathrm{a}}$ & 0.03 \\
\hline Daily protein intake (g/bird/day) & $9.77^{\mathrm{a}}$ & $9.07^{\mathrm{ab}}$ & $8.67^{\mathrm{b}}$ & $8.62^{\mathrm{b}}$ & $8.56^{\mathrm{b}}$ & 0.30 \\
\hline Protein efficiency ratio & $2.83^{\mathrm{a}}$ & $2.29^{\mathrm{b}}$ & $2.29^{\mathrm{b}}$ & $2.24^{\mathrm{b}}$ & $2.29^{\mathrm{b}}$ & 0.03 \\
\hline Mortality (\%) & $2.78^{\mathrm{ab}}$ & $11.11^{\mathrm{a}}$ & $0.00^{\mathrm{b}}$ & $5.55^{\mathrm{ab}}$ & $2.78^{\mathrm{ab}}$ & 2.48 \\
\hline
\end{tabular}

${ }^{\mathrm{a}, \mathrm{b}}$ Means in the same row with different superscripts are highly significantly different $(\mathrm{p}<0.05), \mathrm{SEM}=$ Standard error of mean, ${ }^{\mathrm{ns}}$ Not significantly different ( $>0.05)$.

$\mathrm{CD}=$ Control diet containing $0 \%$ biodegraded sweet orange peel meal, $\mathrm{T}_{1} \mathrm{D}=$ Diet containing sweet orange peel obtained after $12 \mathrm{~h}$ biodegradation, $\mathrm{T}_{2} \mathrm{D}=$ containing sweet orange peel obtained after $24 \mathrm{~h}$ biodegradation, $\mathrm{T}_{3} \mathrm{D}=$ containing sweet orange peel obtained after $36 \mathrm{~h}$ biodegradation, $\mathrm{T}_{4} \mathrm{D}=$ containing sweet orange peel obtained after $48 \mathrm{~h}$ biodegradation.

\section{Conclusion}

The birds fed the biodegraded sweet orange peel (BSOP) based diets had similar final live body weight, body weight gain, feed conversion ratio and protein efficiency ratio. The growth indices for the birds in the BSOP dietary treatments were inferior to the birds on the maize based control diet suggesting that the duration of $12 \mathrm{~h}, 24 \mathrm{~h}, 36 \mathrm{~h}$ and $48 \mathrm{~h}$ given for biodegradation of sweet orange peel did not enhance its nutrients. Biodegradation of sweet orange fruit peel for a time frame of $12 \mathrm{~h}$ to $48 \mathrm{~h}$ yielded a feed ingredient with a relatively high crude fibre, which lowered the growth rate of starter broiler chicks, and hence cannot be used to formulate starter broiler chicks diet at $30 \%$ maize replacement.

\section{References}

[1] Pope, T. and Emmert, J. L. (2001). Phase-Feeding Supports Maximum Growth Performance of Broiler Chicks from Fortythree to Seventy-one Days of age. Journal of Poultry Science, 80: 345-352.
[2] Laudadio, V., Tufarelli, V., Dario, M., D'Emillo, F. P. and Vicenti, A. (2009). Growth performance and carcass characteristics of female turkeys as affected by feeding programs. Journal of Poultry Science, 88: 805-810.

[3] FAO (2012). FAOSTAT. Food and Agriculture Organization of the United Nations.

[4] Jurgens., M. H., Lee, I and Chibam, C. (2009). Poultry Nutrition and Feeding. Animal Nutrition Handbook. 2002; 316 . Available: http://www.ag.auburn.edu/ chibale/an12poultryfeeding.p df

[5] Sobamiwa, O. and Akinwale, T. O. (1999). Replacement value of cocoa husk meal for maize diets in growing pullets. Tropical Journal of Animal Science, 1: 111-116.

[6] Tuleun, C. D., Njike, M. C., Ikurior, S. A. and Ehiobu, N. G. (2005). Laying performance and egg quality of hens fed cassava root meal/brewer's yeast slurry-based diets. Production Agriculture and Technology, 1: 148-152.

[7] Oluremi, O. I. A., Ojighen, V. O and Ejembi, E. H. (2006). The nutritive potentials of sweet orange (Citrus sinensis) in Rind broiler production. International Journal of Poultry Science, 5: 613-617. 
[8] Oluremi, O. I. A., Gabriel, O. S., Ipirakwagh, E. N., Ikwue, C. O. and Afolabi, E. T. (2018). Performance and blood profile of rabbits fed biodegraded sweet orange (Citrus sinensis) peelbased diet. Nigerian Journal of Animal Science, 20 (3): 287-297.

[9] Famurewa, J. A. V. and Olarewaju, A. (2013). Investigating the potentials dried palm oil mill effluents from pressing and water displacement methods for animal feed. Asian Journal of Natural and Applied Science, 2: 58-68.

[10] Orayaga, K. T., Oluremi, O. I. A., Tuleun, C. D. and Carew, S. $\mathrm{N}$ (2015). The feed value of composite mango (Mangifera indica) fruit reject meal in the finisher broiler chickens' nutrition. African Journal of Food Science and Technology, 6 (6): $177-184$

[11] Orayaga, K. T. (2016). Effect of composite mango (Mangifera indica) fruit rejects meal on growth performance, digestibility and economics of production of Rabbits. Nigerian Journal of Animal Science, 1: 65-75.

[12] Olanrewaju, R. I. (2020). Orange Production in Nigeria. Sence Agriculture, Crop Production https://www.agriculturenigeria.com/production/orangeproduction/

[13] Knoema.com (2018). World atlas: Nigeria-Citrus fruit production quantity https://knoema.com/atlas/Nigeria/topics/Agriculture/CropsProduction-Quantity-tonnes/Citrus-fruit-production.

[14] Ipinjolu, J. K. (2000). Performance of juvenile orange koi carp (Cyprinus carpio L.) fed diets supplemented with sweet orange peel meal: body composition, nutrition, utilization and skin pigmentation. Sokoto Journal of Veterinary Science, 2000: 228-229.

[15] Oluremi, O. I. A., Okafor, F. N., Adenkola, A. Y. and Orayaga, K. T (2010). Effect of fermentation of sweet orange (Citrus sinensis) fruit peels on its phytonutrients and performance of broiler starter. International Journal of Poultry Science, 9: 546-549.

[16] Agu, P. N. (2006). Nutritive value of sweet orange (Citrus sinensis) peel as a feed resource in broiler production. Unpublished M. Sc Thesis, Department of Animal Production, University of Agriculture, Makurdi, Nigeria.

[17] Worldometer (2020) Nigeria Population. https://www.worldometers.info/world-population/nigeriapopulation/

[18] Wkipedia (2020). Makurdi: Location in Nigeria. https://en.wikipedia.org/wiki/Makurdi.

[19] Custom Weather (2020). Climate and Weather Averages in Makurdi, Nigeria: Weather Reports Collected between 20052015.

https://www.timeanddate.com/weather/nigeria/makurdi/climat e.

[20] TAC. (2011). Makurdi Weather Element Records. Meteorological station Nigeria Air Force, Tactical Air Command, Makurdi, Nigeria.

[21] A. O. A. C. (2002). Association of Official Analytical Chemists. $17^{\text {th }}$ Edition. William Press. Richard Virginia, USA.

[22] Goering, H. K. and Van Soest, P. J. (1970). Forage fibre analysis. USDA Agricuilture Handbook No. 379. USDA-ARS, Washington, DC.
[23] Pauzenga, U. (1985). Feeding Parent Stock. Journal of Zootecnica International, 19: 22-24.

[24] SPSS.com (2012). IBM ${ }^{\circledR}$ SPSS $^{\circledR}$. Advantage for Micosoft ${ }^{\circledR}$ IBM. Corporation 2012, IBM corporation route, 100 Somers, N4.10589.

[25] Aduku, A. O. (2004). Animal Nutrition in the Tropics. Feeds and Feeding, Pasture management, Monogastric and Ruminant Nutrition, $1^{\text {st }}$ Edition University Press, ABU, Zaria, Nigeria. Pp. 128-134.

[26] Agu, P. N., Oluremi, O. I. A. and Tuleun, C. D. (2010). Nutritional evaluation of sweet orange (Citrus sinensis) fruit peel as feed resources in broiler production. International Journal of Poultry Science, 9 (7): 684-688.

[27] Sunmola, T. A., Tuleun, C. D. and Oluremi, O. I. A. (2018). Performance characteristics of starter broiler chicks fed dietary sun-dried sweet orange peel meal (SOPM) with and without polyzyme ${ }^{\circledR}$. Scientific Research Journal (SCIRJ). 6 (8): 89-97.

[28] Akpe, M. E., Oluremi, O. I. A. and Tuleun, C. D. (2019). Haematological and Serum Biochemical Indices of Broiler Chickens Fed Diets Containing Graded levels of Biodegraded Sweet Orange (Citrus sinensis) Peel. IOSR Journal of Agriculture and Veterinary Science (IOSR-JAVS), 12 (8), 2: 54-59.

[29] Ape, D. I., Nwogu, N. A., Uwakwe, E. I. and Ikedinobi, C. S. (2016). Comparative Proximate Analysis of Maize and Sorghum Bought from Ogbete Main Market of Enugu State, Nigeria. Greener Journal of Agricultural Science, 6 (9): 272 275 .

[30] Aduku, A. O. and Olukosi, J. O. (2000). Animal products processing and handling in the tropics. In: Living book series. $3^{\text {rd }}$ edition, Abuja. G. U. Publications. Pp. 32.

[31] Oluremi, O. I. A., Ngi, J. and Andrew, I. A (2007). Phytonutriets in Citrus fruit peel meal and nutritional implications for livestock production. Livestock Research for Rural Development, 9: 89.

[32] Shi, C., He, J., Yu, J., Yu, B., Huang, Z., Mao, X., Zheng, P. and Chen, P. (2015). Solid state fermentation of rapeseed cake with Aspergillus niger for degrading glucosinolates and upgrading nutritional value. Journal of Animal Science and Biotechnology, 6: 13-19.

[33] Oluremi O. I. A., Ahile A. A. and Jande T. F (2017). Effect of feeding graded levels of fermented sweet orange (Citrus sinensis) fruit peel meal on the growth and nutrient digestibility of broiler chicken. International Journal of Environment, Agriculture and Biotechnology, 2: 3119-3123.

[34] Nwobodo, E. A., Oluremi, O. I. A, Tuleun, C. D. and Kaankuka, F. G. (2020). The effect of Biodegraded Sweet Orange (Citrus Sinensis) Fruit Peel on the Growth and Economic Performance of Starter Broiler Chicks. Journal of Animal Husbandry and Dairy Science, 4 (1): 23-29.

[35] Oluremi, O. I. A., Mou, P. M. and Adenkola, A. Y. (2008). Effect of sweet orange (Citrus sinensis) fruit peels on its maize replacement value in broiler diet. Livestock Research for rural Development, 20: 246-298. 